\title{
ЕФЕКТИВНІСТЬ ДОРОЩУВАННЯ ПОРОСЯТ 3 ВИКОРИСТАННЯМ У КОМБІКОРМАХ ОКСИДУ ЦИНКУ ТА АМОКСИЦИЛІНУ
}

\author{
Опара Віктор Олексійович \\ кандидат сільськогосподарських наук, доцент \\ Сумський національний аграрний університет \\ ORCID: 0000-0002-8917-4423 \\ E-mail: vopara@ukr.net
}

Попсуй В'ячеслав Васильович кандидат сільськогосподарських наук, доцент Сумський національний аграрний університет ORCID: 0000-0002-3487-0923 E-mail: vvp72@ukr.nett

Корж Ольга Василівна кандидат сільськогосподарських наук, доцент Сумський національний аграрний університет ORCID: 0000-0002-9134-5148

E-mail: korg.olga@ukr.net

Романченко Михайло Юрійович студент магістратури Сумський національний аграрний університет ORCID: 0000-0002-5253-7729

E-mail: dubrdun@gmail.com

На виробництві часто зустрічаються випадки, коли в перші два тижні після відлучення від свиноматки у поросят спостерігаються розлади травлення невідомої етіології. Першопричиною цієї проблеми є стресове навантаження на організм поросят. Дієвими методами боротьби з розладами травлення в цей період є правильний підбір антибіотиків $i$ введення до складу комбікорму оксиду цинку. Досліджувалась ефективність застосування амоксициліну та оксиду цинку в комбікормах для годівлі поросят після відлучення. Експериментальні дослідження проводилися на групах помісного молодняку свиней в умовах промислового комплексу ПрАТ "Агропромислова компанія". Комплексне введення до складу комбікормів в період дорощування оксиду цинку в кількості 1,5 ка на 1 тону в період 49-63 дня та амоксищиліну в кількості 0,5 ке на 1 тону в період 30-48 дня і 0,2 ке на 1 тону в період 49-62 дня сприяє підвищенню інтенсивності росту молодняку та покращує конверсію кормів та збереженість поросят. Середня жива маса поросят дослідної групи перевищувала ко-

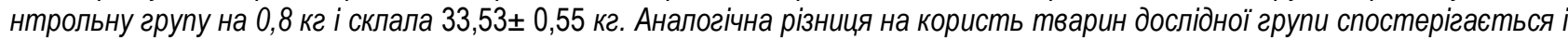
за показниками абсолютних та середньодобових приростів. За показником збереженості перевага на користь рекомендованої схеми вирощування з використанням оксиду цинку та амоскициліну склала 3,4%. Застосування даної системи годівлі поросят після відлучення є економічно вигідною, адже дозволить підвищити як інтенсивність росту молодняку за період вирощування так і покращити конверсію кормів.

Ключові слова: поросята, дорощування, амосксицилін, оксид цинку, приріст, конверсія корму

DOI: https://doi.org/10.32845/bsnau.Ivst.2021.4.18

Продуктивність свиней та якість отримуваної від них продукції визначається як породними особливостями тварин, методами розведення, умовами утримання, так і значною мірою рівнем та повноцінністю їх годівлі $[4,9,13]$. Головними викликами для промислового свинарства насьогодні $€$ максимізація ефективності використання кормів при мінімізації виробничих витрат та впливу на навколишнє середовище [ $8,15,16]$

Серед основних фракторів, які стримують виробництво свинини в державі $є$ проблеми з кормовою базою і, в більшій мірі, саме з концентрованими зерновими кормами, що впливає на вартість і якість комбікормів, а відтак, підвищує собівартість продукції на всіх етапах вирощування свиней [ $3,6,10,14]$.

у свинарстві найбільш відповідальним моментом всього технологічного ланцюга виробництва свинини $\epsilon$

відлучення поросят від свиноматок. На виробництві часто зустрічаються випадки, коли в перші два тижні після відлучення від свиноматки у поросят спостерігаються розлади травлення невідомої етіології. Першопричиною цієї проблеми $€$ стресове навантаження на організм поросят.

Дієвими методами боротьби з розладами травлення в цей період є правильний підбір антибіотиків і введення до складу комбікорму оксиду цинку. Ці методи допомагають вирішенню проблеми, а саме знижують відхід поросят та підвищують прирости. Однак застосування антибіотиків у період вирощування свиней не $є$ безпечним і заборонено в ряді країн.

Оксид цинку - це джерело важливого мікроелементу, що регулює секрецію кишкових пептидів, які стимулюють споживання кормів. Його включення до раціону пригальмовує розвиток патогенних бактерій. Але з організму тварин

Вісник Сумського національного аграрного університету 
виводиться переважно у незміненому вигляді. Відомо, що цинк пригнічує зростання деяких патогенних бактерій (наприклад, E. coli), він $€$ компонентом багатьох фрерментів, що беруть участь в обміні речовин та функціях імунної системи поросят, і виконує протизапальну дію. Використання оксиду цинку для профілактики проносів набагато безпечніший i дешевший, немає ризику розвитку дисбактеріозу, не витрачається дорогоцінний час на підбір дієвого препарату, знижується необхідність застосування антибіотиків, тим самим підвищуються якісні показники м'яса. Але цинк належить до групи важких металів та небезпечний, а через низьку засвоюваність потрібна велика кількість оксиду цинку [12].

Цинк відіграє в організмі важливу роль, але швидке надходження цинку 3 кормом має один великий недолік створення конкуренції для інших мінеральних речовин. Використання кормів з підвищеним вмістом цинку, навіть дуже короткий період після відлучення, знижує засвоєння інших важливих мікроелементів, наприклад, магнію, міді або заліза. Високі дозування оксиду цинку застосовуються для поліпшення стану шлунково-кишкового тракту поросят і підвищення їх імунного статусу. Введення 3000 г оксиду цинку на тонну комбікорму протягом перших двох тижнів після відлучення поросят збільшує майже на $30 \%$ загальну кількість цинку, що виділяється з екскрементами за повний період відгодівлі. В результаті можуть виникнути екологічні проблеми. Зазвичай цинк додається в корм у вигляді оксиду цинку або сульфату цинку. Це дешеві кормові добавки, але цинк при цьому засвоюється не повністю. Застосування оксиду цинку є прийнятним варіантом у раціонах поросят у тих країнах, де він не заборонений[12].

Одним з дієвих заходів профілактики діарей у поросят після відлучення $€$ застосування дієвих та дозволених антибіотиків. Амоксицилін - антибактеріальний препарат групи напівсинтетичних пеніцилінів, що має широкий спектр антимікробної дії. Амоксицилін за ступенем впливу на організм відноситься до помірно небезпечних речовин. Антибактеріальний спектр дії амоксициліну включає широкий спектр дії щодо таких бактерій, як Staphylococcus spp., Streptococcus spp. Haemophilus spp., Corynebacterium spp., Brucella spp., Shigella spp., Clostridium spp., Fusobacterium necrophorum, Erysipelothrix rhusiopthiae, Listeria monocytogenes.

Мета досліджень - вивчення продуктивності молодняку свиней в період дорощування при годівлі комбікормами, до складу яких включено оксид цинку та амоксицилін.

Матеріали та методи досліджень. Експериментальні дослідження проводилися на групах помісного молодняку свиней в умовах промислового комплексу ПрАТ "Агропромислова компанія". На початку дослідження кількість поросят в групах та їх жива маса були аналогічними, що відповідає встановленим вимогам[1].

Для вивчення ефективності застосування амоксициліну та оксиду цинку в комбікормах для поросят після відлучення було розроблено методику досліджень, згідно якої контрольна група вирощувалась на комбікормах власного виробництва, за схеми їх використання та рецептури, що наведені в таблицях 1 та 2. Вміст в комбікормах енергії, поживних, мінеральних та біологічно-активних речовин та їх добове споживання в цілому відповідало встановленим нормам годівлі $[2,7]$

Поросята дослідної групи додатково з комбікормами одержували амоксицилін та оксид цинку в кількості, що зазначена в наведеній нижче таблиці.

Таблиця 1

Умови годівлі поросят дослідної і контрольної груп

\begin{tabular}{|c|c|c|c|}
\hline Період дорощування, днів & Споживання корму за період, кг & \multicolumn{2}{|c|}{ Умови годівлі } \\
\cline { 3 - 4 } & 10,5 & Контрольна група & Дослідна група \\
\hline $30-48$ & 9,1 & OP & $\begin{array}{c}\text { ОР + амоксицилін } \\
\text { (0,5 2 на 1 ка комбікорму })\end{array}$ \\
\hline $49-63$ & 31,5 & OP & $\begin{array}{c}\text { OP + амоксицилін + оксид цинку } \\
\text { (0,2 та 1,5 г на 1 кг комбікорму) }\end{array}$ \\
\hline $64-88$ & OP & OP \\
\hline
\end{tabular}

Для вивчення продуктивних якостей піддослідних тварин враховували: живу масу (кг), середньодобовий приріст (г), показник збереженості (\%) [11]. По закінченню дослідження було вирахувано середню кількість витраченого комбікорму на одне порося на добу і на 1 кг приросту.

Матеріали досліджень опрацьовували на ПК за використання програмного забезпечення за формулами, описаними Е. К. Меркурьевою[5].

Результати досліджень. Рецепти комбікормів, що використовувались для годівлі поросят у період дорощування, та їх поживність представлено у табл. 2. Аналізуючи наведені в таблиці дані, зазначимо, що склад комбікормів, їх якість та поживність відповідають діючим нормам. До складу комбікормів крім зернової групи включено якісні білкові корми, премікс, синтетичні амінокислоти, смакові та ароматичні добавки, підкислювачі, ферментні препарати. Таким чином забезпечується найкраще споживання та ефективне перетравлення корму при забезпеченні належного стану здоров'я. Цілий комплекс вітамінних та мінеральних добавок запобігає розладам травлення і розвитку побічної мікрофлори кишківника, але не містить антибіотиків; сприяє активному розвитку органів травлення, підвищує споживання стартового комбікорму, а також загальну резистентність організму поросят; має високий вміст критичних амінокислот, регульовану кількість доступного фосфору, високу ступінь засвоювання мінеральних речовин і вітамінів. 
Таблиця 2

Склад та поживність комбікормів для молодняку на дорощуванні

\begin{tabular}{|c|c|c|c|c|}
\hline \multirow{2}{*}{ Корми та добавки } & \multicolumn{4}{|c|}{ Для поросят віком, днів } \\
\hline & Старт (до 30) & $30-48$ & $49-63$ & $61-88$ \\
\hline \multicolumn{5}{|c|}{ Склад комбікорму , \% } \\
\hline Ячмінь & $8,00^{* *}$ & 10,00 & 15,00 & 32,50 \\
\hline Пшениця & $14,00^{*}$ & 8,00 & 18,80 & 32,61 \\
\hline Кукурудза & $15,22^{*}$ & $33,076^{*}$ & 28,330 & - \\
\hline Горох & $3,50^{*}$ & - & - & $9,00^{*}$ \\
\hline Соєва макуха & - & - & 15,50 & 12,00 \\
\hline Соєвий шрот & 21,10 & 18,60 & 10,00 & 5,00 \\
\hline Соняшникова макуха & - & - & - & 5,00 \\
\hline Висівки пшеничні & 7,30 & 8,00 & 8,00 & - \\
\hline Сироватка суха & 11,00 & 5,7 & - & - \\
\hline Соєва олія & 1,50 & 1,00 & 0,52 & - \\
\hline Крейда & 0,18 & 0,42 & 0,71 & 0,90 \\
\hline Сіль & - & - & 0,30 & - \\
\hline Кормові фосфрати & - & 0,004 & 0,30 & - \\
\hline Премікс & - & - & 2,5 & 2,5 \\
\hline Концентрат АПК & 15,00 & 15,00 & & \\
\hline \multicolumn{5}{|c|}{ На 100 кг комбікорму додається, г } \\
\hline Органічні кислоти & - & - & 400 & 400 \\
\hline Сорбент мікотон & - & 200 & 200 & 50 \\
\hline Фермент технозим & - & - & 20 & - \\
\hline Лізин & - & - & 290 & 40 \\
\hline Метеонін & - & - & 70 & - \\
\hline Треонін & & & 70 & - \\
\hline \multicolumn{5}{|c|}{ В 1 кг комбікорму міститься } \\
\hline ОЕ, МДж & 14,42 & 13,54 & 13,35 & 12,90 \\
\hline Сирий протеїну, г & 200 & 185 & 180 & 176 \\
\hline Лізину, г & 15,2 & 13,8 & 12,8 & 12,0 \\
\hline Метіонін +цистину, г & 9,0 & 8,4 & 7,50 & 6,7 \\
\hline
\end{tabular}

Результати науково-господарського експерименту, що було проведено протягом осені 2020 року, представлено в табл. 3. По завершенні періоду дорощування середня жива маса поросят дослідної групи перевищувала контрольну групу на 0,8 кг і склала 33,53 кг але різниця була не вірогід-

ною. Аналогічна різниця на користь тварин дослідної групи спостерігається і за показниками абсолютних та середньодобових приростів. Їх значення склало 25,7 кг та 444 г, що більше на 0,6 кг та 13 г відповідно.

Результати вирощування поросят дослідної та контрольної груп

\begin{tabular}{|l|c|c|c|}
\hline \multicolumn{1}{|c|}{ Показники } & Контрольна група & Дослідна група & \pm до контролю \\
\hline Кількість поросят на початку досліду & 90 & 90 & 0 \\
\hline Середня жива маса поросят при відлученні(30 днів), кг & $7,82 \pm 0,35$ & $7,79 \pm 0,31$ & $-0,03$ \\
\hline Кількість поросят в кінці дорощування & 83 & 86 & +3 \\
\hline Середня жива маса поросят в кінці дорощування(88 днів), кг & $32,91 \pm 0,46$ & $33,53 \pm 0,55$ & $+0,8$ \\
\hline Збереженість, \% & 92,2 & 95,6 & $+3,4$ \\
\hline Абсолютний приріст за період, кг & $25,1 \pm 1,02$ & $25,7 \pm 1,16$ & $+0,6$ \\
\hline Середньодобовий приріст, г & $431 \pm 8,4$ & $444 \pm 9,5$ & +13 \\
\hline Фактичні витрати корму на 1 гол., кг & 51,1 & 50,7 & $+0,4$ \\
\hline Конверсія & 2,04 & 1,98 & $-0,06$ \\
\hline
\end{tabular}

За показником збереженості перевага на користь рекомендованої схеми вирощування з використанням оксиду цинку та амоскициліну склала $3,4 \%$.

Заслуговує уваги також той факт, що поросята дослідної групи в період 49-63 дня трохи гірше споживали корми, але в цілому за дослідний період різниця була не суттєвою, лише 0,4 кг на голову. Це, очевидно пояснюється гірким присмаком оксиду цинку. Кращою у поросят дослідної групи була і конверсія корму, 1,98 кг проти 2,04 кг на 1 кг приросту в контролі.
Таким чином, застосування оксиду цинку та амоксициліну в складі комбікормів при дорощуванні поросят є доцільним, оскільки при цьому спостерігається покращення збереженості поросят(на 3,4 \%), підвищується інтенсивність росту та конверсія кормів.

Економічна оцінка результатів досліджень по комплексному використанню оксиду цинку та амоксициліну при вирощуванні поросят після відлучення представлено в таблиці 4. 
Таблиця 4

Ефективність системи годівлі поросят на дорощуванні з використанням оксиду цинку та амоксициліну

\begin{tabular}{|c|c|c|c|}
\hline Показники & Контрольна група & Дослідна група & \pm до контролю \\
\hline Кількість поросят на початку досліду & 90 & 90 & 0 \\
\hline Середня жива маса поросят при відлученні, кг & 7,8 & 7,8 & 0 \\
\hline Загальна жива маса поросят, кг & 702 & 702 & 0 \\
\hline Кількість поросят в кінці дорощування & 83 & 86 & +3 \\
\hline Середня жива маса поросят в кінці дорощування, кг & 32,9 & 33,5 & $+0,8$ \\
\hline Загальна жива маса поросят в кінці дорощування, кг & 2731 & 2881 & +150 \\
\hline Збереженість, \% & 92,2 & 95,6 & $+3,4$ \\
\hline Кількість спожитих комбікормів за період, кг & 4241 & 4360 & +139 \\
\hline Приріст за період, кг & 2029 & 2179 & +150 \\
\hline Середньодобовий приріст живої маси, г & 431 & 444 & +13 \\
\hline Конверсія корму за період, кг/на 1 кг приросту & 2,04 & 1,98 & $-0,06$ \\
\hline Споживання корму за період на 1 гол., кг & 51,1 & 50,7 & $-0,4$ \\
\hline Середня вартість 1кг комбікорму, грн. & 12,50 & 12,93 & $+0,43$ \\
\hline Вартість витрачених комбікормів в розрахунку на 1 гол., грн. & 53012 & 56375 & +3363 \\
\hline Інші витрати*, грн. & 22719 & 23787 & +1068 \\
\hline Всього витрат на вирощування., грн. & 75731 & 80536 & +3559 \\
\hline Виробнича собівартість 1 кг приросту & 27,45 & 27,27 & $-0,18$ \\
\hline
\end{tabular}

* - 30 \% в структурі собівартості

Аналіз наведених даних показує, що в розрахунку на групу (90 гол.) комплексне застосування даних препаратів забезпечує одержання 150 кг додаткового приросту, що в розрахунку на 1 гол., що була поставлена на дорощування складає 1,67 кг.

Із розрахунків також видно, що застосування даної системи годівлі поросят після відлучення $€$ економічно вигідною, адже дозволить підвищити як інтенсивність росту молодняку до 444 г (+13 г порівняно з контролем) г за період вирощування так і покращити конверсію кормів. Хоча включення до складу комбікормів оксиду цинку та амоксициліну підвищує його вартість на 3,4\%, це повністю компенсується, адже розрахункова собівартість приросту в дослідній групі $\epsilon$ меншою на 0,18 грн. і складає 27,27 грн.

Наведені вище показники та їх обґрунтування доводять можливість ефективного використання наведеної системи вирощування поросят після відлучення.

Висновки. 1. Комплексне введення до складу комбікормів в період дорощування оксиду цинку в кількості 1,5 кг на 1 тону в період 49-63 дня та амоксициліну в кількості
0,5 кг на 1 тону в період 30-48 дня і 0,2 кг на 1 тону в період 49-62 дня сприяє підвищенню інтенсивності росту молодняку та покращує конверсію кормів та збереженість поросят.

2. Середня жива маса поросят дослідної групи перевищувала контрольну групу на 0,8 кг і склала 33,53 0,55 кг. Аналогічна різниця на користь тварин дослідної групи спостерігається і за показниками абсолютних та середньодобо-

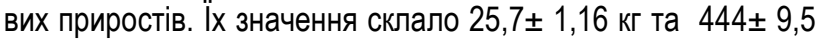
г, що більше на 0,6 кг та 13 г відповідно. За показником збереженості перевага на користь досліджуваної схеми вирощування з використанням оксиду цинку та амоскициліну склала $3,4 \%$.

3. Застосування даної системи годівлі поросят після відлучення є економічно вигідною, адже дозволить підвищити як інтенсивність росту молодняку за період вирощування та покращити конверсію кормів. Хоча включення до складу комбікормів оксиду цинку та амоксициліну підвищує його вартість ефрективність його використання $€$ кращою, адже розрахункова собівартість 1 кг приросту в дослідній групі $\epsilon$ меншою на 0,18 грн.

\section{Список використаної літератури:}

1. Викторов П.И., Менькин В.К. Методика и организация зоотехнических опытов. М.: Агропромиздат, 2001. 112 с.

2. Дурст Л., Виттман М. Кормление сельсъкохозяйственных животных / Под ред.ИМ. Ибатуллина, Г.В. Проваторова: пер. с немецкого. Винница: Нова Книга, 2003. 384 с.

3. Куян Н. Качественного комбикорма без кормовых добавок не существует. Ефективні корми та годівля. 2011. № 1. C. 6-8.

4. Лихач В. Я., Лихач А. В. Технологічні інновації у свинарстві. К.: ФОП Ямчинський О. В., 2020. 291 с.

5. Меркурьева Е.К. Биометрия в животноводстве. М.: Колос, 1984. 311 с.

6. Михалко О.Г. Сучасний стан та шляхи розвитку свинарства в світі та Україні. Вісник Сумського національного аграрного університету. Серія «Тваринництво», 2021, Вип. 3(46), С. 61-78.

http://repo.snau.edu.ua/bitstream/123456789/9537/1/6.pdf

7. Норми, раціони і поживність кормів для різних видів сільськогосподарських тварин: Довідник / Г.В. Проваторов, В.І. Ладика, Л.В. Бондарчук, В.О. Проваторова, В.О. Опара. Суми, 2007. 357 с.

8. Практикум з годівлі сільськогосподарських тварин: навчальний посібник [Ібатуллін І.І., Мельник Ю.Ф., Отченашко В.В.,та ін.];під ред. академіка НААН України І.І. Ібатулліна. - К.: 2015. 422 с.

9. Проваторов Г.В., Проваторова В.О. Годівля сільськогосподарських тварин: Підручник. Суми: ВТД „Університетська книга", 2004. 510 с.

10. Свинарство: Монографрія/за ред. В. М. Волощука. К.: Аграр. наука, 2014. 592 с.

11. Сучасні методики досліджень у свинарстві. Полтава, 2005. 228 с. 
12. Шастак Е. Цинк в кормлении свиней. Взаимодейсвие с фитатом и фитазой. Комбикорма. №10. 2015. C 63-64.

13. Шпетный Н.Б., Михалко А.Г. Интенсивность роста, сохранность и конверсия корма поросятами летом при содержании их в станках с разным типом пола // Актуальные проблемы интенсивного развития животноводства : матер. XXI Межд. науч.-практ. конф. Горки, 2018. Ч. 1. С.108-116.

14. Юлевич О. І., Лихач А. В., Дехтяр Ю. Ф. Оцінка залежності показників росту підсисних та відлучених поросят від складу раціонів. Науковий бюлетень ІТ УААН. Харків, 2016. Вип. 115. С. 258-263.

15. Andretta, I., C. Pomar , J. Rivest, J. Pomar, and J. Radünz. 2016. Precision feeding can significantly reduce lysine intake and nitrogen excretion without compromising the performance of growing pigs. Animal10:1137-1147. doi:10.1017/S1751731115003067

16. Strid Eriksson, I., H. Elmquist, S. Stern, and T. Nybrant. 2005. Environmental systems analysis of pig production - the impact of feed choice (12 pp). Int. J. Life Cycle Assess.10(2):143-154. doi: 10.1065/lca2004.06.160

\section{References:}

1. Viktorov P.I., Menkin V.K., 2001. Metodyka y orhanyzatsyia zootekhnycheskykh opыtov [Methods and organization of zootechnical experiments]. M.: Ahropromyzdat.

2. Durst L., Vyttman M., 2003. Kormlenye selsъkokhoziaistvennыkh zhyvotnыkh [Feeding farm animals]. M.: Vynnytsa.

3. Kuian N., 2011. Kachestvennoho kombykorma bez kormovыkh dobavok ne sushchestvuet [There is no quality compound feed without feed additives]. Effective feed and feeding, issue 1, pp. 6-8.

4. Lykhach V. Y., Lykhach A. V., 2020. Tekhnolohichni innovatsii u svynarstvi [Technological innovations in pig breeding]. K.: FOP Yamchynskyi O. V.

5. Merkureva E.K., 1984. Byometryia v zhyvotnovodstve [Biometrics in animal husbandry]. M.: Kolos.

6. Mykhalko O.G., 2021. Suchasnyi stan ta shliakhy rozvytku svynarstva v sviti ta Ukraini [Current state and ways of pig breeding development in the world and in Ukraine]. Bulletin of Sumy National Agrarian University, series "Livestock", issue 3(46), pp. 61-78. DOI: http://repo.snau.edu.ua/bitstream/123456789/9537/1/6.pdf

7. Provatorov G. V., 2007. Normy hodivli, ratsiony i pozhyvnist kormiv dlia riznykh vydiv silskohospodarskykh tvaryn : dovidnyk [Feeding rates, rations and nutritional value of feed for different species of farm animals: a guide]. Sums: VTD University Book LLC.

8. Ibatullin I.I, Melnyk Y.F, Otchenashko V.V., 2015. Praktykum z hodivli silskohospodarskykh tvaryn: navchalnyi posibnyk [Workshop on feeding farm animals: a textbook]. K. Kiev.

9. Provatorov H.V., Provatorova V.O., 2004. Hodivlia silskohospodarskykh tvaryn [Feeding farm animals]. Sumy.

10. Voloshchuka V. M., 2014. Svynarstvo [Swine breeding]. K.: Ahrar. nauka.

11. Suchasni metodyky doslidzhen u svynarstvi [Modern research methods in pig breeding]. Poltava.

12. Shastak E., 2015. Tsynk v kormlenyy svynei. Vzaymodeisvye s fytatom y fytazoi [Zinc in pig feeding. Interaction with phytate and phytase]. Compound feed, issue 10, pp. 63-64.

13. Shpetny N. B., Mikhalko A. G., 2018. Yntensyvnost rosta, sokhrannost y konversyia korma porosiatamy letom pry soderzhanyy ykh v stankakh s raznыm typom pola [Growth intensity, safety and conversion of feed by piglets in summer when kept in machines with different types of sex]. Actual problems of intensive development of animal husbandry: mater. XXI Int. scientificpractical conf. Bitter, issue 1, pp.108-116.

14. Yulevych O.I., Likhach A.B., Dehtyar Y.F., 2016. Otsinka zalezhnosti pokaznykiv rostu pidsysnykh ta vidluchenykh porosiat vid skladu ratsioniv [Estimation of dependence of growth indicators of suckling and weaned piglets on the composition of rations]. UAAS IT Scientific Bulletin. Kharkiv, issue 115, pp. 258-263.

15. Andretta, I., C. Pomar, J. Rivest, J. Pomar, and J. Radünz., 2016. Subtilitas pascendi signanter minuere potest attractio lysine et excretionem NITROGENIUM sine detrimento porcorum crescendi faciendi [Precision feeding can significantly reduce lysine intake and nitrogen excretion without compromising the performance of growing pigs].Animal10:1137-1147. doi:10.1017/S1751731115003067

16. Strid Eriksson, I., H. Elmquist, S. Stern, and T. Nybrant, 2005. Environmental systemata analysis productionis suse impulsum electionis pascendi [Environmental systems analysis of pig production - the impact of feed choice ]. Int. J. Life Cycle Assess.10(2):143-154. doi: 10.1065//ca2004.06.160

Opara Viktor Oleksiiovych, PhD of Agricultural Sciences, Docent

Popsui Viacheslav Vasylovych, PhD of Agricultural Sciences, Docent

Korzh Olha Vasylivna, PhD of Agricultural Sciences, Docent

Romanchenko Mykhailo Yuriiovych, master's student

Sumy national agrarian university (Sumy, Ukraine)

Efficiency of growing pigs used in compound feed zinc oxide and amoxycilin.

Digestive disorders of unknown etiology are common in piglets during the first two weeks after weaning. The root cause of this problem is the stress on the body of piglets. Effective methods of combating digestive disorders during this period are the correct selection of antibiotics and the introduction of zinc oxide in the feed. The effectiveness of amoxicillin and zinc oxide in compound feeds for weaning piglets after weaning was studied. Experimental studies were conducted on groups of local young pigs in the industrial complex of PJSC "Agroindustrial Company". Complex introduction to the composition of feed in the period of growth of zinc oxide in the amount of $1.5 \mathrm{~kg}$ per 1 ton in the period of 49-63 days and amoxicillin in the amount of $0.5 \mathrm{~kg}$ per 1 ton in the period of 30-48 days and $0.2 \mathrm{~kg}$ per 1 ton in the period of 49-62 days helps to increase the intensity of growth of young animals and improves 
feed conversion and safety of piglets. The average live weight of piglets in the experimental group exceeded the control group by 0.8 $\mathrm{kg}$ and amounted to $33.53 \mathrm{~kg}$. A similar difference in favor of the animals of the experimental group is observed in terms of absolute and average daily gains. According to the preservation indicator, the advantage in favor of the recommended scheme of cultivation using zinc oxide and amoskycillin was $3.4 \%$. The use of this system of feeding piglets after weaning is economically viable, because it will increase both the growth rate of young animals during the rearing period and improve feed conversion.

Key words: piglets, rearing, amoxicillin, zinc oxide, growth, feed conversion.

Дата надходження до редакції: 02.12.2021 р. 